\title{
Strengths-Based Analysis of Student Success in Online Courses
}

\author{
Carol S. Gering, Dani K. Sheppard, Barbara L. Adams, Susan L. Renes, and Allan A. Morotti
}

University of Alaska Fairbanks

\begin{abstract}
Online courses today give a broad, diverse population access to higher education. Despite postsecondary institutions embracing this opportunity, scholarly literature reveals persistent concern over low retention rates in online courses. In response to this concern, an explanatory sequential, mixed methods study was conducted in three phases at a public research university to simultaneously explore personal, circumstantial, and course variables associated with student success from a strengths-based perspective. In Phase One, existing data on student enrollments across four years were analyzed. During Phase Two, a subset of Phase One students from a single semester was invited to complete an assessment of noncognitive attributes and personal perceptions, followed in Phase Three by interviews among a stratified sample of successful students from the previous phase to elaborate on factors impacting their success. Quantitative analyses identified seven individual variables with statistical and practical significance for online student success. Interestingly, the combination of factors classified as predictive of success changed with student academic standing. The impact of differential success factors across academic experience may explain mixed results in previous studies. The themes that emerged from the interviews with students were congruent with quantitative findings. A unique perspective was shared when students discussed "teaching themselves," providing additional insight into perceptions of teaching presence not formerly understood. The combination of a more contextual research approach, a strengths-based perspective, and insights from student perceptions yielded implications for educational practice.
\end{abstract}

Keywords: online learning, online education, student success, student perception, teaching presence, higher education, postsecondary, strengths-based, mixed methods

Gering, C.S., Sheppard, D.K., Adams, B.L., Renes, S.L., \& Morotti, A.A. (2018). Strengthsbased analysis of student success in online courses. Online Learning, 22(3), 55-85.

doi:10.24059/olj.v22i3.1464

\section{Strengths-Based Analysis of Student Success in Online Courses}

Enrollment in online courses at degree-granting higher education institutions within the U.S. grew at an exponential rate during the first decade of this century (Allen, Seaman, Poulin, \& 
Straut, 2016). Between fall 2002 and fall 2011, the compound annual growth rate for U.S. students taking at least one online course was 17.3\% (Allen \& Seaman, 2013). Since 2011, online enrollments have continued to climb while on-campus enrollments have decreased (Allen et al., 2016). The growth in online learning can possibly be explained by the convergence of several trends. A broader, more diverse population has entered higher education facilitated by advances in technology which allow students to access content anywhere at any time (Herbert, 2006; Layne, Boston, \& Ice, 2013). As a result, many higher education institutions have prioritized online education as a strategic approach to increase enrollment (Clinefelter \& Aslanian, 2016). At the same time, campaigns promoting the need for more Americans to participate in higher education have emerged both at national and at state levels, prompting more nontraditional students to enroll in postsecondary courses (Carnevale, Strohl, \& Smith, 2009; Kelderman, 2013; Soares, 2013). Students who enter college immediately after high school, live on campus, and attend full-time in pursuit of a four-year degree, categorized as traditional students (Soares, 2013), are no longer the norm, as most students enrolled in higher education in the U.S. today are, in fact, nontraditional students (National Adult Learner Coalition, 2017).

Meanwhile, fewer campus-based students take face-to-face classes exclusively without including one or more online courses in their class schedules (Allen \& Seaman, 2017). A majority of postsecondary universities in the U.S. have therefore embraced online learning as part of their long-term strategy. In fact, more than $60 \%$ of chief academic leaders consider online education critical to their institution's long-term strategy. These institutions continue to expand online programs as on-campus enrollments decline (Allen et al., 2016).

Despite rapid enrollment growth and institutional acceptance, many academic leaders express concern over poor retention rates among online students (Allen \& Seaman, 2013; Berge \& Huang, 2004; Park \& Choi, 2009). A number of scholars have reported completion rates among online and distance courses to be significantly lower than for face-to-face courses (Boston, Ice, \& Gibson, 2011; Jaggars \& Xu, 2010; Lokken, 2017; Rovai, 2003). Higher education is faced with increasing numbers of students enrolling in online courses despite the possibility that they may not complete them. This dilemma represents a waste of resources for both the student and the institution (Simpson, 2006). It is, therefore, essential that colleges and universities understand issues related to student attrition and find ways to improve persistence in online courses (Ekstrand, 2013; Herbert, 2006). The current study addressed this need using a strengths-based perspective to examine student success in online courses.

\section{Review of Related Literature}

Much is still unknown about student success in online courses. Scholars have researched postsecondary achievement for decades, but the history of online learning itself is relatively short. During the first decade of this century, online pedagogies evolved as new technologies began to mature. Research into student success in the online environment has not yet coalesced into a strong body of consistent evidence. Many variables contributing to success have only been examined in a single study, while those that have been examined in multiple studies have produced conflicting results (Clark, 2013; Wang, Shannon, \& Ross, 2013).

As one example of contradictory results, Cochran, Campbell, Baker, and Leeds' (2014) study of undergraduate students at a large state university found a positive correlation between age and online course completion for two groups: students who did not receive scholarships and those 
without student loans. Many other studies found no correlation between age and student success in online courses (Aragon \& Johnson, 2008; Baturay \& Yukselturk, 2015; Gibson, Kupcynski, \& Ice, 2010; Guidry, 2013; Harrell \& Bower, 2011).

A second example of antithetical results related to race or ethnicity. Several studies found no relationship with student success in online learning (Aragon \& Johnson, 2008; Gibson et al., 2010; Harrell \& Bower, 2011; Jost, Rude-Parkins, \& Githens, 2012). Some, however, found race combined with other factors yielded a significant association with success (Cochran et al., 2014; Rockinson-Szapkiw, Wendt, Wighting, \& Nisbet, 2016; Suphi \& Yaratan, 2012).

In addition to the problem of conflicting evidence discussed above, meta-analyses reveal that studies to date show little consistency in factors considered and approaches used. Some scholars, for example, have approached online student outcomes by studying dropout factors, while others have examined persistence factors (Hart, 2012; Lee \& Choi, 2011). With regard to the inconsistency in factors examined, Lee and Choi (2011) reviewed scholarly research published between 1999 and 2009, looking for empirical data on variables that influence students' decision to drop out of postsecondary online courses. They identified a wide variety of 69 factors, typically investigated in isolation. The authors further proposed categorizing these variables into three broad categories - student factors, course/program factors, and environmental factors - and addressed in their conclusions the need for future studies to address interrelationships between these three clusters, as opposed to narrow, independent evaluations of a single type of variables.

In contrast to Lee and Choi's (2011) focus on dropout factors, Hart (2012) conducted an integrated literature review of articles published between 1999 and 2011 that addressed students' ability to persist in online courses. Similar to Lee and Choi's (2011) conclusions about interrelationships, Hart noted that persistence is a complex variable that may not be directly related to knowledge acquisition at all. A student's decision to persist may be influenced by a combination of factors both internal and external to the university, such as personal motivation, time to graduation, communication with the instructor, and family support.

Glazier's (2016) review of scholarly work described three broad categories of explanations for the lower success rates of online courses compared to classroom courses: (a) student characteristics, including both demographics and academic preparedness; (b) the student's environment; and (c) course design and interaction. Few studies to date have examined these three categories in combination. Researchers who did look at all three addressed student satisfaction with the course but did not include variables of course design and interaction (Baturay \& Yukselturk, 2015; Levy, 2007; Wang et al., 2013). Studies that evaluated course design and interaction typically did not include independent variables of students' personal characteristics and circumstances (Hegeman, 2015; Jaggers \& Xu, 2010; Liu, Gomez, \& Yen, 2009; Olson \& McCracken, 2014). Evaluating personal, circumstantial, and course factors simultaneously requires a more complex research design. While some of these data are most reliable when retrieved from official university information systems, others require asking students directly. Noncognitive attributes and perceptions, in particular, necessitate a carefully designed assessment tool.

The rationale for considering all three variable types together aligns with the sustainable student retention model proposed by Berge and Huang (2004). This theoretical model was built as a framework allowing institutions to add variables to three clusters (personal, circumstantial, and institutional), and to prioritize the relative importance of the three areas within the institutional 
context (Berge \& Huang, 2004). This theoretical framework was adapted for the current study by changing institutional variables to course variables. Because the same institution delivered all course enrollments included in this research, there were no differing institutional variables to consider. Course-specific elements were examined instead, as a subset of institutional characteristics.

Examining the reasons students leave college applies a pathology-based approach to the problem (Shushok \& Hulme, 2006). Strengths-based approaches, on the other hand, attempt to identify "what is right" with students rather than diagnosing "what is wrong" (Lopez \& Louis, 2009; Shushok \& Hulme, 2006; Stebleton, Soria, \& Albecker, 2012). Moreover, deficit-based research often separates people from the context in which they live, while strengths-based research promotes an ecological view of the relationship between subjects and their circumstances (Maton et al., 2004). This implicit emphasis on context made the strengths-based perspective a natural choice for the current study.

The strengths-based perspective originated in the field of social work as an alternative to the deficit-based focus on dysfunction. Saleebey (2006) articulated a number of underlying principles of the strengths perspective, including the belief that "every individual, group, family, and community has strengths" (p. 16). Although strengths-based practice acknowledges problem behaviors, solutions are pursued by highlighting the individual's competencies, resources, and values (Shaima \& Narayanan, 2018). Basic tenets of this perspective align with the field of positive psychology, which focuses on the study of strengths, well-being, and optimal functioning (Lee Duckworth, Steen, \& Seligman, 2005). Proponents from a variety of fields have embraced these ideals in support of social justice, racial equity, and cultural inclusion (e.g., Craven et al., 2016; Dew, Anderson, Skogrand, \& Chaney, 2017; Fenton, Walsh, Wong, \& Cumming, 2014; Stebleton, Soria, \& Albecker, 2012; Veney et al., 2016; Watt, Norton, \& Jones, 2013).

\section{Purpose and Significance of the Study}

The current study, including both undergraduate and graduate students, was undertaken to understand factors associated with student success, with the goal of supporting persistence and increasing educational attainment. In applied practice, strengths-based approaches seek to understand and build upon the strengths of an individual or group. However, prior to applying strengths-based assessments or interventions, it is necessary to understand, through research, which characteristics might be perceived as strengths. For example, before publishing the Clifton StrengthsFinder as an assessment tool, Clifton and his colleagues identified thoughts, feelings, and behaviors associated with situational success by studying top performers in a variety of roles and settings (Asplund, Lopez, Hodges, \& Harter, 2007). Likewise, Shushok and Hulme (2006) assert that the first step toward implementing a strengths-based approach on a college campus is to study and understand successful students. Strengths-based research does not ignore those who may be considered unsuccessful, but it begins with a focus on those who are successful to first learn the proper variables of interest.

An explanatory sequential, mixed method design was selected to complement the strengths-based approach. By definition, explanatory sequential research begins with quantitative measures and continues with qualitative (Cresswell, 2011). Because the literature review yielded contradictory evidence, this study sought an opportunity to explain results from the quantitative phases in more depth through qualitative follow-up. Data collection and analysis proceeded sequentially: quantitative methods were used to examine correlation between 28 variables and 
student success in online courses. Qualitative methods were subsequently employed to explain and elaborate on factors identified through quantitative means. Qualitative interviews captured the voices and viewpoints of successful students. The current study addressed five related questions:

1. To what extent do personal variables, circumstantial variables, or course variables account for student success in asynchronous online courses?

2. To what extent can a combination of personal, circumstantial, and course variables be used to predict success in asynchronous online courses?

3. How do successful online students perceive the impact of personal, circumstantial, and course variables in their educational experience?

4. How do successful online students define their role versus the instructor's role, and how do they believe each role contributes to student success?

5. How have successful online students been able to overcome challenges and persist to completion?

Personal, circumstantial, and course variables examined in this study are listed in Tables 1 and 2.

\section{Methods}

\section{Study Setting and Population}

The current investigation was conducted in three phases at the University of Alaska Fairbanks (UAF), a public doctoral university whose primary campus is located in interior Alaska. UAF serves nearly 10,000 students, $88 \%$ of whom are undergraduates. One distinctive characteristic of this institution is the breadth of credentials granted: UAF offers workforce development and vocational programs, as well as baccalaureate degrees, master's degrees, and PhDs. In other words, the public community college mission is embedded within this university. The range of degree levels offered by this single university provided an opportunity to explore success factors across the academic spectrum.

This study examined students who took online courses via UAF eLearning. The eLearning unit is responsible for supporting all asynchronous online courses offered through UAF academic departments. More than 25 eLearning staff members provide centralized instructional design, faculty development and support, enrollment management, and student services for online courses and programs. Limiting the study to eLearning-supported courses ensured many aspects of the course design, delivery, and support were consistent, resulting in a more controlled analysis of variables. Phase One began by examining the archived records of all students who took online courses through UAF eLearning over the course of four academic years (fall 2011 through spring 2015). Students included in this research were located across the state and beyond, as shown in Figure 1. 


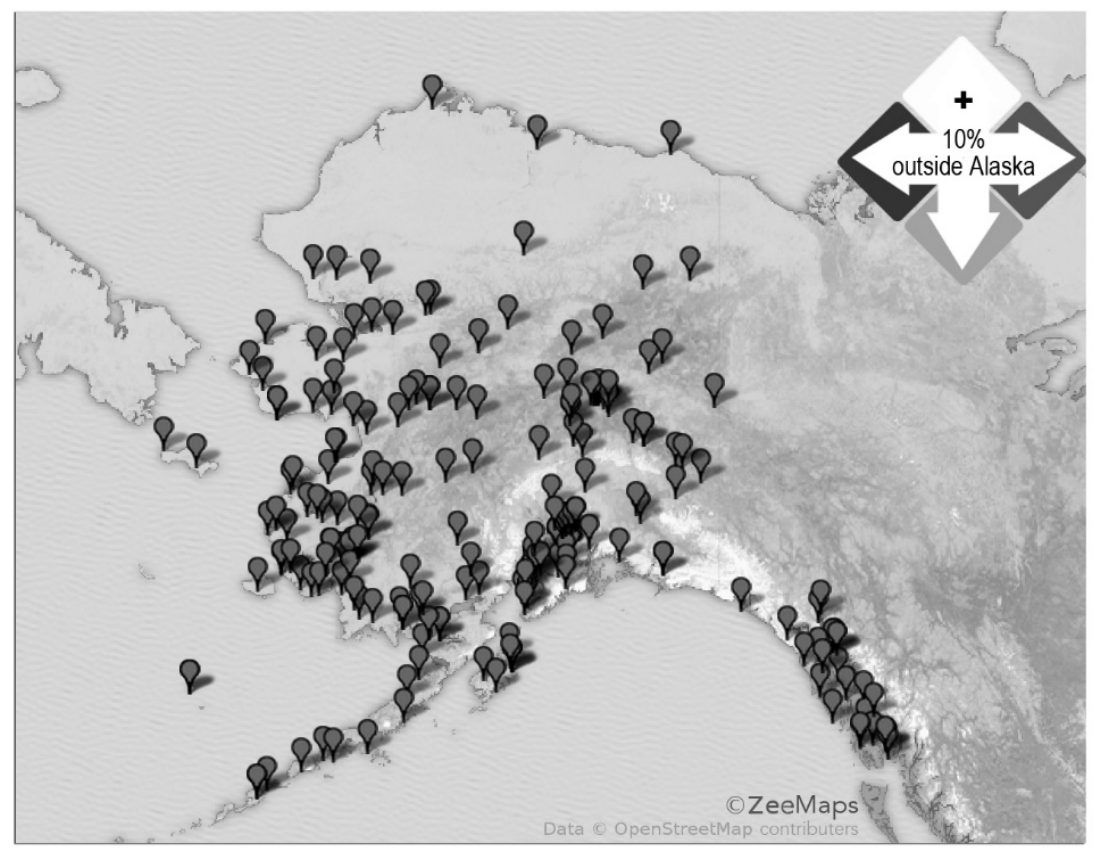

Figure 1. Student locations within Alaska. Map created with ZeeMaps and used by permission.

Pursuant to the explanatory sequential design, the list of participants was narrowed in each phase to provide tighter focus and support additional data collection. Figure 2 depicts the sequence and scope for each of the three phases.

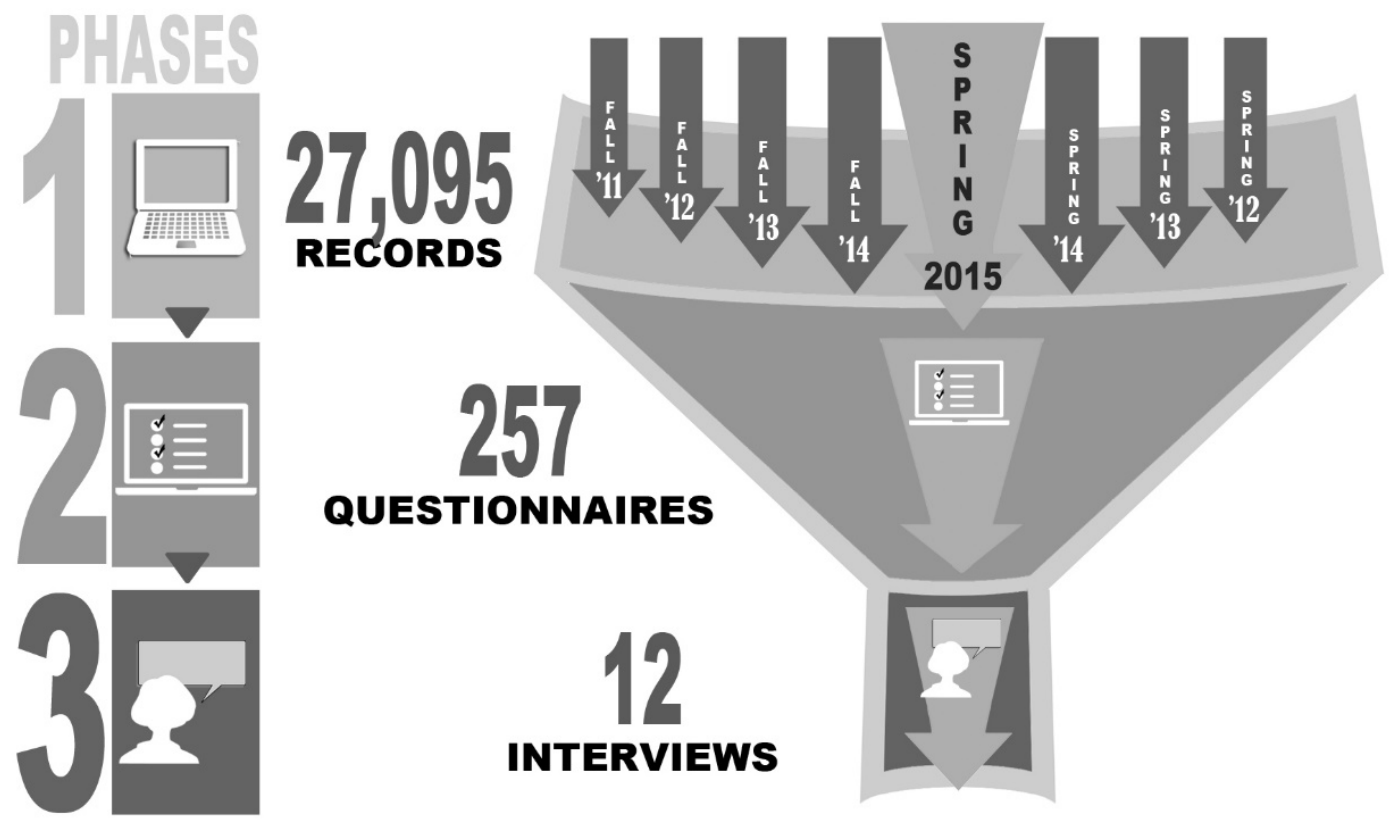

Figure 2. Research conducted in three phases using an explanatory sequential design. 
Phase One participants. The first phase of research examined 27,095 enrollments, each defined as a distinct student within a specific course for a given semester. This was not 27,095 unique students but rather distinct student-course-semester combinations. Each case, therefore, represented a distinct combination of course, circumstantial, and personal variables.

Phase Two participants. Participants in Phase Two included enrollments from the latest semester in the Phase One dataset, with the expectation that students might recall details more vividly for the most recent semester. While Phase One used archived data, Phase Two queried participants for additional information, using perspectives drawn from psychology, sociology, and education. All 2,581 students having taken fully online courses in spring 2015 were invited to complete a questionnaire. In contrast to Phase One, which included every enrollment, in Phase Two all students were invited to participate once, regardless of how many online courses they took during the spring 2015 semester. Forty percent of the spring 2015 students took more than one online course that semester; for these students the invitation indicated the course randomly selected for inclusion in the study.

Phase Three participants. Candidates for Phase Three were identified from the list of successful students who completed the Phase Two questionnaire. Because Phase One analyses revealed differential predictors of success across class standing, a stratified random sample was drawn for Phase Three that included two students from each class standing. The random sample was not constrained to stratify for gender, because Phase One analyses revealed no association between gender and success. In total, 12 students were interviewed, including 10 females and two males.

\section{Phase One Data Collection and Analyses}

The definition of student success for Phase One was operationalized as a final course grade of $\mathrm{C}$ - or higher, because UAF academic regulations recognize $\mathrm{C}$ - as the minimum passing grade that signifies sufficient mastery to advance in the academic sequence. Each case was then coded as either a successful or unsuccessful course completion. Archived data for all online students were retrieved from the University of Alaska student information system. Informed by the evidencebased theoretical framework selected (Berge \& Huang, 2004), extracted data were clustered into categories of personal, circumstantial, and course variables. The summary presented in Table 1 outlines the classification of Phase One variables by category and by whether they were dichotomous, nominal, or ordinal. 
Table 1.

Phase One Independent Variables

\begin{tabular}{|c|c|c|}
\hline Personal Variables & Circumstantial Variables & Course Variables \\
\hline D Gender & (D First-time eLearning Student & E Course Level \\
\hline D UA Scholar & (D eLearning Courses Only & Class Size \\
\hline (D) International Student & (D) Full-time Student & \\
\hline D Active Military & Degree Level & \\
\hline (1) UA Athlete & Financial Aid & Key: \\
\hline Race & Location & $D=$ dichotomous \\
\hline Age & Class Standing & $=$ nominal \\
\hline E Cumulative GPA & & = ordinal \\
\hline
\end{tabular}

Note. UA refers to University of Alaska.

Data analyses. Variables were analyzed for association with student success by means of Crosstabulations with chi-square tests for independence. Cramér's V was used to evaluate effect size. Logistic regression was then used to examine whether a combination of the 17 variables could be used to predict success. The fact that many students were successful in some courses and unsuccessful in others underscored the importance of evaluating personal, circumstantial, and course variables in combination. Data analyses were performed using SPSS, version 22. A significance level of .05 was used in all statistical tests.

The general regression model used was (Gordon, 2015):

$$
\operatorname{Logit}(\hat{Y})=b_{0}+b_{1} X_{1 \ldots} b_{17} X_{17}
$$

Where $\hat{Y}$ is success, $X_{1}$ is gender, $X_{2}$ is UA Scholar, $X_{3}$ is international student, $X_{4}$ is active military, $X_{5}$ is UA athlete, $X_{6}$ is race, $X_{7}$ is age, $X_{8}$ is cumulative grade point average, $X_{9}$ is first-time eLearning student, $X_{10}$ is eLearning courses only, $X_{11}$ is full-time student, $X_{12}$ is degree level, $X_{13}$ is financial aid, $X_{14}$ is location, $X_{15}$ is class standing, $X_{16}$ is course level, and $X_{17}$ is class size.

\section{Phase Two Data Collection and Analyses}

Additional information was collected in Phase Two by means of an online questionnaire. The Phase Two instrument included three nonscale questions targeting circumstantial variables and 60 scale questions designed to measure noncognitive motivational factors and student perceptions, using questions from the following instruments with permission of the authors: 
1. Perceived Academic Control (PAC) developed by Perry, Hladkyj, Pekrun, and Pelletier (2001).

2. The General Self-Efficacy Scale (Schwarzer \& Jerusalem, 2009). For use in this study, questions were reworded to provide an academic focus.

3. Theories of Intelligence Scale-Self Form for Adults (Dweck, 2013).

4. Multidimensional Scale of Perceived Social Support (MSPSS) developed by Zimet, Dahlem, Zimet, and Farley (1988).

5. Teaching Presence, from the Community of Inquiry (CoI) model (Garrison, Anderson, \& Archer, 2000).

6. Social Presence, from the CoI model (Garrison et al., 2000).

A practical question arose when combining these scales into a single instrument: whether to keep the questions grouped (i.e., locus of control questions grouped together, self-efficacy questions grouped together, etc.) or whether to mix the questions randomly. A second, related question was whether to use the scale values from the original instruments or modify the values to be the same throughout the questionnaire. Results of preliminary exploration supported the decision to randomize questions and make scale values consistent. Questions included in the Phase Two instrument are included in the Appendix.

Data analyses. Because these scales had not previously been used together in a single assessment, exploratory factor analysis (EFA; Williams, Brown, \& Onsman, 2010) was used to examine scale structure and the relationship between variables. Eight factors were identified from the questionnaire responses. A total scale score was calculated for each participant for each of the eight factors, using the total of constituent question scores. Visual examination of the histogram for each scale - using each participant's total score — revealed that responses on all eight scales were negatively skewed:

- PAC: skewness of -1.315 $(S E=0.152)$ and kurtosis of $1.805(S E=0.303)$

- Self-Efficacy: skewness of $-0.738(S E=0.152)$ and kurtosis of $0.546(S E=0.303)$

- Incremental Theory Mindset: skewness of $-0.553(S E=0.152)$ and kurtosis of $-0.191(S E=0.303)$

- Perceived Social Support of a Special Person: skewness of -1.546 (SE=0.152) and kurtosis of $1.666(S E=0.303)$

- Perceived Social Support of Friends: skewness of -0.593 $(S E=0.152)$ and kurtosis of $-0.202(S E=0.303)$

- Perceived Social Support of Family: skewness of -0.871 $(S E=0.152)$ and kurtosis of $0.637(S E=0.303)$

- Teaching Presence: skewness of $-0.952(S E=0.152)$ and kurtosis of $0.649(S E=$ 0.303)

- Social Presence: skewness of $-0.223(S E=0.152)$ and kurtosis of $-0.409(S E=$ $0.303)$ 
Due to the nonparametric distribution, the mean value of each participant's scale scores were therefore categorized with binary values of high or low on each scale. Mean scale scores of 4.0 to 5.0 were categorized as high, while scores below 4.0 were classified low. Nonparametric techniques were also used on all subsequent analyses. Table 2 displays the resulting Phase Two variables, including the eight scales and three additional (nonscale) variables.

Table 2.

Phase Two Independent Variables

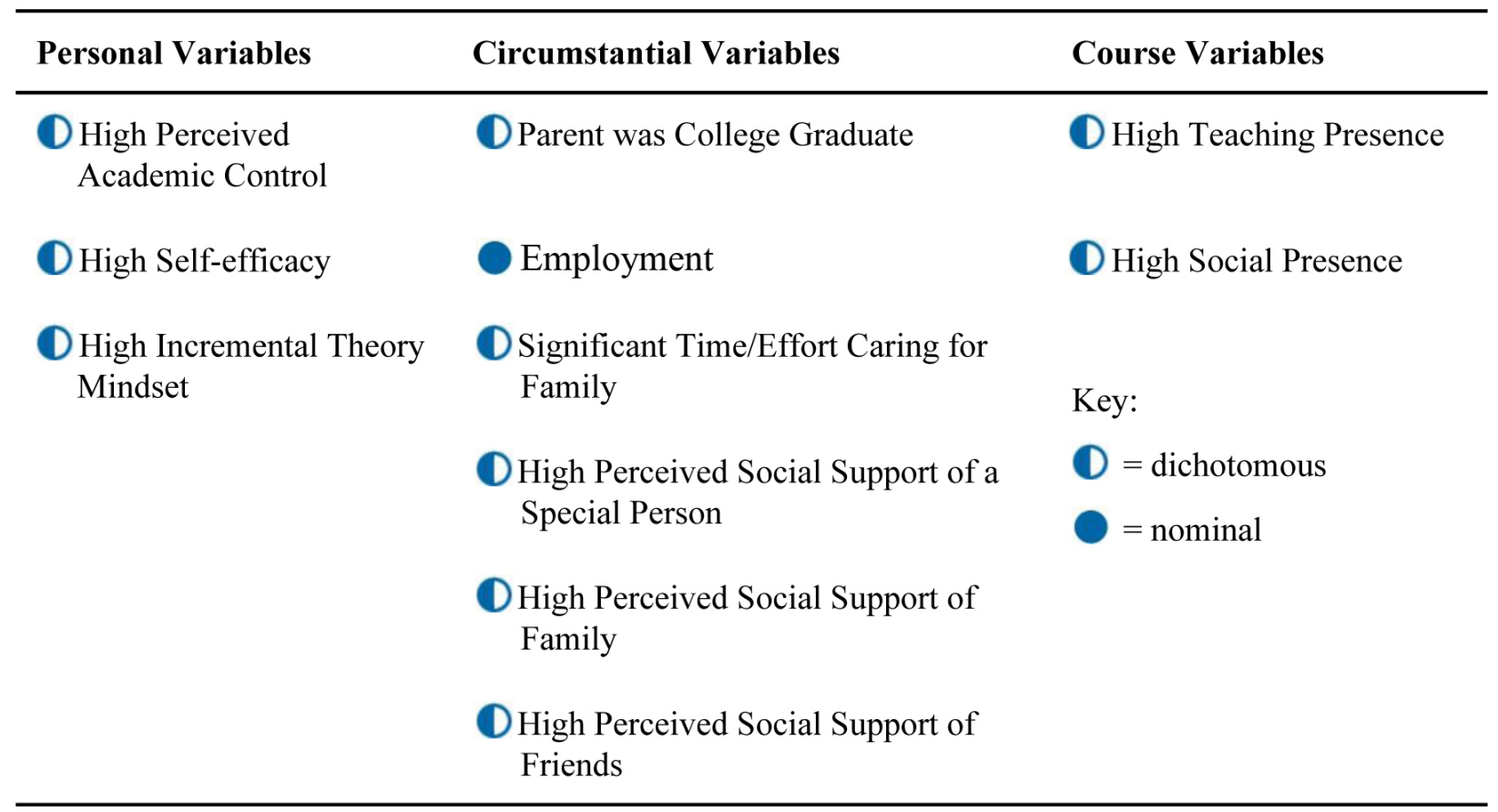

Focus on success. The original intent was to compare responses of successful and unsuccessful students in Phase Two. However, an evaluation of Phase Two data revealed a disproportionate number of responses from students categorized as successful, with a final course grade of C- or higher. The low rate of return from the nonsuccess group (only 41 out of 303 participants) limited the likelihood of drawing statistically significant conclusions about students who did not complete their online course successfully. Therefore, in alignment with the strengthbased approach, analyses focused on responses from successful students, using the ordinal level of final course grade rather than binary measure of success/nonsuccess. Five participants were subsequently removed who had received a "P" (pass) grade. Analyses for Phase Two proceeded with the 257 respondents who earned final course grades of $\mathrm{C}$ - to $\mathrm{A}+$.

Crosstabulations were used to assess the distribution of Phase Two variables across final grade categories. Somers' delta was chosen to assess strength and direction of the association. High scale scores with a statistically significant correlation to final grade were subsequently assessed by means of Mann-Whitney U tests. 


\section{Phase Three Data Collection and Analyses}

During Phase Three, 12 individual interviews were conducted, recorded, and transcribed. Questions used in the interview protocol were informed by an earlier pilot study. NVivo qualitative data analysis software supported a two-stage process of coding and analysis. During the first cycle, aligned with methods described by Saldaña (2009), provisional coding was used to highlight sections of interview transcripts related to quantitative variables in the first two phases. Provisional coding was congruent with the explanatory sequential research design, creating a natural transition between quantitative and qualitative phases of research. Furthermore, the use of provisional coding formed the foundation for holistic, combined analysis of data from all three phases.

Upon completion of provisional coding, elaborative coding was used to corroborate the theoretical framework of personal, circumstantial, and institutional variables, and to expand on the concept of student roles versus instructor roles that emerged from the pilot of potential interview questions. Elaborative coding enabled identification of additional themes and offered an opportunity to capture illustrative phrases in the participants' own words, which was central to the strengths-based research design. Following qualitative analysis, results from all three phases were considered comprehensively.

\section{Results}

Three phases of data collection and analysis were completed sequentially. Participants in Phase Three were a subpopulation of Phase Two, which was a subpopulation of Phase One. Slightly more than half $(52.9 \%)$ of the total cases studied were full-time students. More than one third were taking online courses exclusively, while $62.2 \%$ took a combination of online and faceto-face courses. Basic demographic information for participants in all three phases is displayed in Table 3. 
Table 3.

Demographic Description of Participants

\begin{tabular}{|c|c|c|c|c|c|c|}
\hline \multirow[t]{2}{*}{ Variable } & \multicolumn{2}{|c|}{ Phase One } & \multicolumn{2}{|c|}{ Phase Two } & \multicolumn{2}{|c|}{ Phase Three } \\
\hline & $n$ & $\%$ & $n$ & $\%$ & $n$ & $\%$ \\
\hline \multicolumn{7}{|l|}{ Gender } \\
\hline Female & 18,334 & 67.7 & 179 & 69.6 & 10 & 83.3 \\
\hline Male & 8,761 & 32.3 & 78 & 30.4 & 2 & 16.7 \\
\hline \multicolumn{7}{|l|}{ Race } \\
\hline Undisclosed & 7,903 & 29.2 & 66 & 25.7 & 2 & 16.7 \\
\hline Asian & 579 & 2.1 & 5 & 1.9 & 0 & 0.0 \\
\hline Black & 826 & 3.0 & 4 & 1.6 & 0 & 0.0 \\
\hline Hawaiian/Pac. Island & 183 & 0.7 & 2 & 0.8 & 0 & 0.0 \\
\hline Native/Indian & 3,739 & 13.8 & 28 & 10.9 & 1 & 8.3 \\
\hline White & 13,865 & 51.2 & 152 & 59.1 & 9 & 75.0 \\
\hline \multicolumn{7}{|l|}{ Age } \\
\hline Under 20 & 3,378 & 12.5 & 40 & 15.6 & 5 & 41.7 \\
\hline $20-24$ & 9,586 & 35.4 & 89 & 34.6 & 2 & 16.7 \\
\hline $25-29$ & 5,010 & 18.5 & 50 & 19.5 & 2 & 16.7 \\
\hline $30-39$ & 5,509 & 20.3 & 42 & 16.3 & 2 & 16.7 \\
\hline $40-49$ & 2,324 & 8.6 & 22 & 8.6 & 1 & 8.3 \\
\hline 50 and over & 1,288 & 4.8 & 14 & 5.4 & 0 & 0.0 \\
\hline \multicolumn{7}{|l|}{ Class Standing } \\
\hline Non-degree-seeking & 2,728 & 10.1 & 22 & 8.6 & 2 & 16.7 \\
\hline First-time freshman & 1,080 & 4.0 & 3 & 1.2 & 0 & 0.0 \\
\hline Freshman, not first time & 4,197 & 15.5 & 26 & 10.1 & 2 & 16.7 \\
\hline Sophomore & 5,306 & 19.6 & 47 & 18.3 & 2 & 16.7 \\
\hline Junior & 5,251 & 19.4 & 51 & 19.8 & 2 & 16.7 \\
\hline Senior & 7,504 & 27.7 & 74 & 28.8 & 2 & 16.7 \\
\hline Graduate student & 1,029 & 3.8 & 34 & 13.2 & 2 & 16.7 \\
\hline \multicolumn{7}{|l|}{ Degree Level } \\
\hline Non-degree-seeking & 2,728 & 10.1 & 22 & 8.6 & 2 & 16.7 \\
\hline Occupational endorse. & 125 & 0.5 & 1 & 0.4 & 0 & 0.0 \\
\hline Certificate & 1,369 & 5.1 & 7 & 2.7 & 1 & 8.3 \\
\hline Associate & 6,496 & 24.0 & 35 & 13.6 & 0 & 0.0 \\
\hline Bachelors & 15,345 & 56.6 & 158 & 61.5 & 7 & 58.3 \\
\hline Post-bac./licensure & 154 & 0.6 & 2 & 0.8 & 1 & 8.3 \\
\hline Master's & 800 & 3.0 & 29 & 11.3 & 1 & 8.3 \\
\hline $\mathrm{PhD}$ & 78 & 0.3 & 3 & 1.2 & 0 & 0.0 \\
\hline Total Cases $=$ & 27,095 & & 257 & & 12 & \\
\hline
\end{tabular}


Table 4.

Course Characteristics

\begin{tabular}{|c|c|c|c|c|c|c|}
\hline \multirow[t]{2}{*}{ Variable } & \multicolumn{2}{|c|}{ Phase One } & \multicolumn{2}{|c|}{ Phase Two } & \multicolumn{2}{|c|}{ Phase Three } \\
\hline & $n$ & $\%$ & $n$ & $\%$ & $n$ & $\%$ \\
\hline \multicolumn{7}{|l|}{ Course Level } \\
\hline Developmental & 414 & 1.5 & 1 & 0.4 & 0 & 0.0 \\
\hline Lower & 19,002 & 70.1 & 152 & 59.1 & 6 & 50.0 \\
\hline Upper & 6,413 & 23.7 & 63 & 24.5 & 3 & 25.0 \\
\hline Professional & 139 & 0.5 & 0 & 0.0 & 0 & 0.0 \\
\hline Graduate & 1,127 & 4.2 & 41 & 16.0 & 3 & 25.0 \\
\hline \multicolumn{7}{|l|}{ Class Size } \\
\hline Less than 15 & 3,897 & 14.4 & 48 & 18.7 & 4 & 33.3 \\
\hline $15-30$ & 11,636 & 42.9 & 107 & 41.6 & 5 & 41.7 \\
\hline $31-45$ & 7,356 & 27.1 & 66 & 25.7 & 2 & 16.7 \\
\hline $46-60$ & 2,501 & 9.2 & 21 & 8.2 & 1 & 8.3 \\
\hline More than 60 & 1,705 & 6.3 & 15 & 5.8 & 0 & 0.0 \\
\hline \multicolumn{7}{|l|}{ High Teaching Presence } \\
\hline Yes & & & 137 & 53.3 & 2 & 16.7 \\
\hline No & & & 120 & 46.7 & 10 & 83.3 \\
\hline \multicolumn{7}{|l|}{ High Social Presence } \\
\hline Yes & & & 83 & 32.3 & 2 & 16.7 \\
\hline No & & & 174 & 67.7 & 10 & 83.3 \\
\hline Total Cases = & 27,095 & & 257 & & 12 & \\
\hline
\end{tabular}

\section{Phase One Results}

Five of 17 variables collected in Phase One and displayed in Table 1 showed statistical and practical association with student success as measured by crosstabulations with chi-square tests for independence and Cramér's V analysis of effect size (Table 5). Cumulative GPA produced the largest effect size, $\chi^{2}(4, n=26,538)=5,909.55, p=.000$, Cramér's V $=0.47$. 
Table 5.

Chi-Square and Cramér's V Among Significant Phase One Variables

\begin{tabular}{|c|c|c|c|c|}
\hline & $\begin{array}{c}\text { Pearson } \\
\text { Chi-Square }\end{array}$ & $d f$ & $\begin{array}{c}\text { Asymp. Sig. } \\
\text { (2-sided) }\end{array}$ & Cramér's V \\
\hline Cum. GPA (personal) & $5,909.549$ & 4 & .000 & 0.472 \\
\hline $\begin{array}{l}\text { Class Standing } \\
\text { (circumstantial) }\end{array}$ & 595.660 & 6 & .000 & 0.148 \\
\hline Course Level (course) & 494.101 & 4 & .000 & 0.135 \\
\hline $\begin{array}{l}\text { Degree Level } \\
\text { (circumstantial) }\end{array}$ & 342.947 & 7 & .000 & 0.113 \\
\hline Race (personal) & 323.448 & 5 & .000 & 0.109 \\
\hline
\end{tabular}

Binomial logistic regression revealed cumulative GPA as a significant predictor of student success. Entry of cumulative GPA into the logistic regression model significantly improved model fit (null $-2 \mathrm{LL}=31124.25, \chi^{2}=5766.33, p<.001$ ). As displayed in Table 6, odds of student success in an online course increased with each categorical level of cumulative GPA.

Table 6.

Logistic Regression Results, Predicting Odds of Success Based on Cumulative GPA

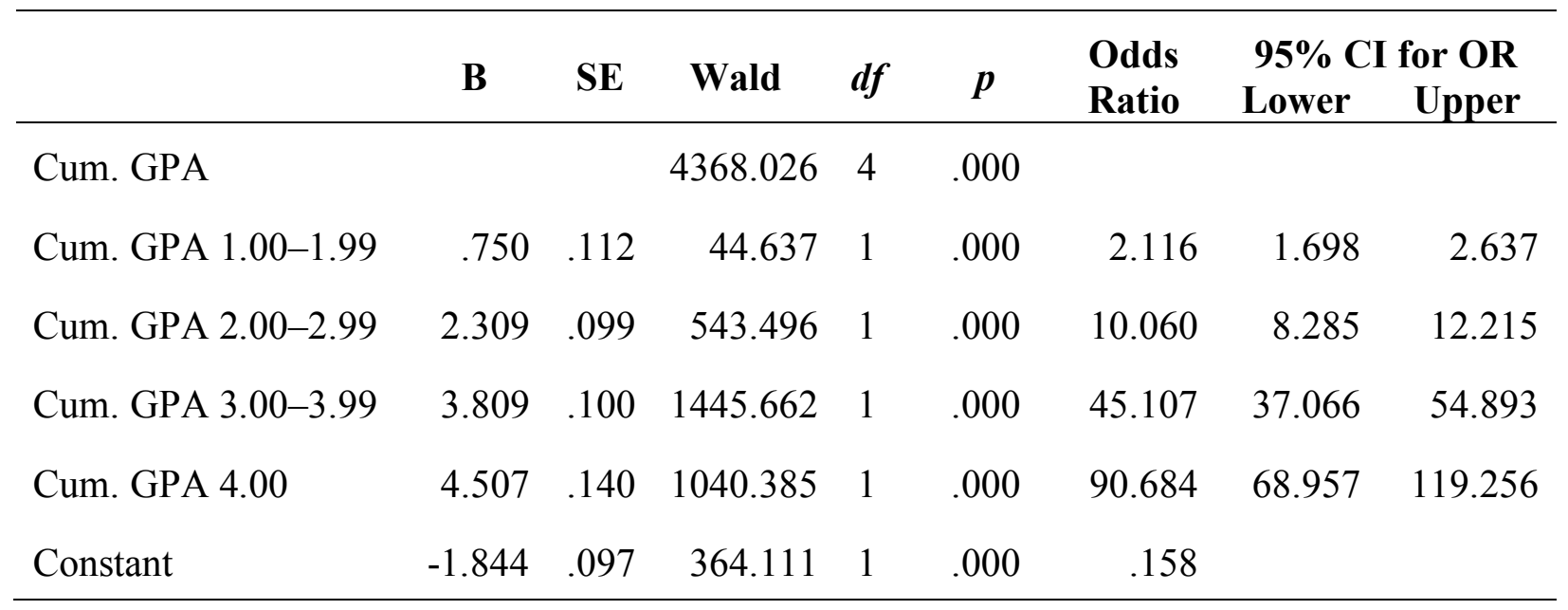

Further analyses explored whether a combination of variables could be used to predict success. To do so, the dataset was divided into subgroups by class standing to address issues of multicollinearity and mutual exclusion (e.g., class standing and degree level; associate-level degree program and graduate level courses). Logistic regression analyses were conducted for each 
class-standing group, using the forward conditional entry method. Figure 3 summarizes logistic regression results and the variance explained by each model, revealing that variables contributing to student success differed by class standing. For nondegree students, a five-factor model (cumulative GPA, gender, race, first-time eLearning, and eLearning courses exclusively) explained $12.9 \%$ of variance, increasing accurate classification of cases from $65.2 \%$ to $78.1 \%$. For first-time freshmen, a three-factor model explained $17.8 \%$ of variance in accurate classification. Improvements in classification of success showed subsequent decline for each successive class standing group. Although the three-factor model for graduate students produced a statistically significant result, the variance explained was too small to be practically significant.

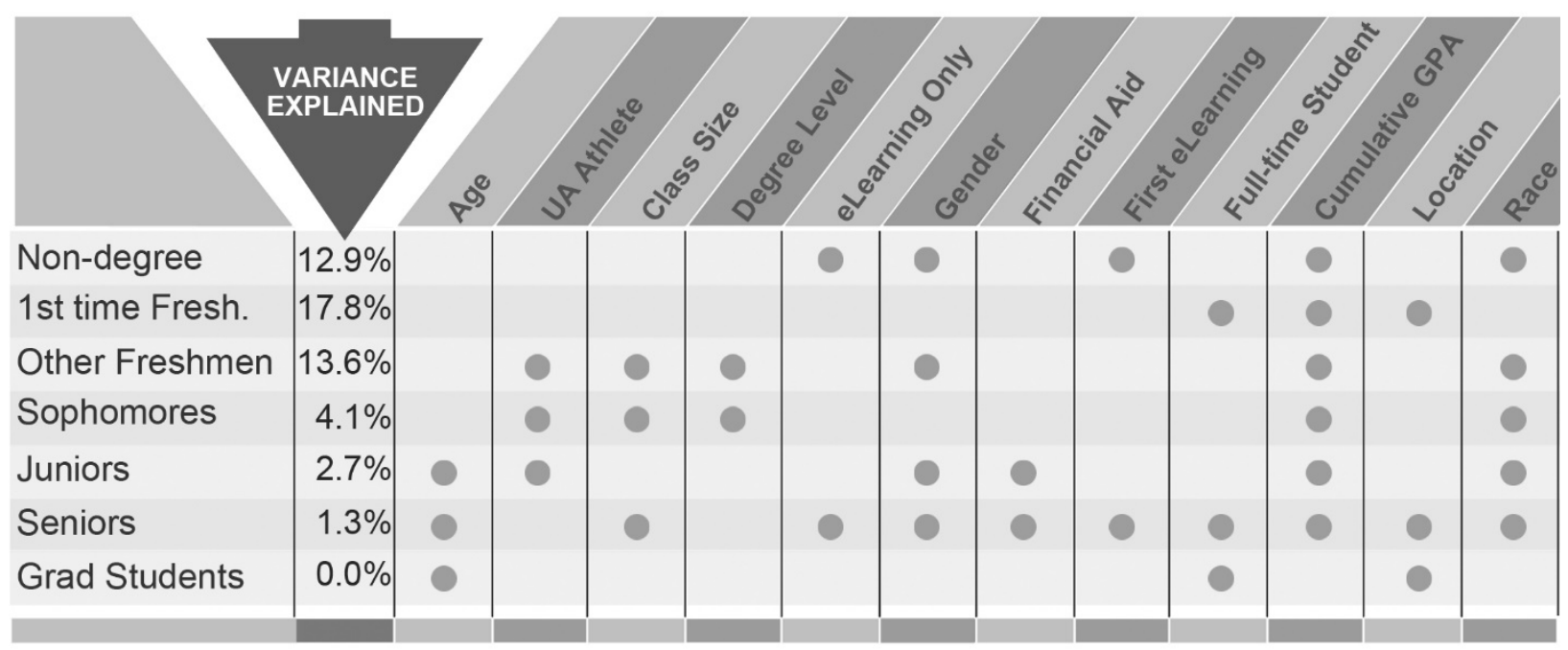

Figure 3. Summary of logistic regression results and the variance explained by each class-standing model.

\section{Phase Two Results}

Of the 2,581 students invited to participate in Phase Two, 320 submitted the questionnaire, producing a response rate of $12.4 \%$. After removing 17 responses due to errors or incongruity, EFA was performed to create a factor structure. Initial extraction using principal axis factoring (PAF) produced 10 factors with eigenvalues above 1.0. After visual examination of the scree plot, eight factors were retained. Cronbach's alpha provided evidence of good internal consistency for each of the eight factors, with alpha scores ranging from 0.83 to 0.97 . The final list of eight scalebased variables and three nonscale variables were displayed in Table 2 . As previously discussed, low response rate from nonsuccessful students led to an adjustment in the research design. The remaining Phase Two analyses were conducted on responses from 257 students who earned final course grades of $\mathrm{C}$ - to $\mathrm{A}+$. With this change, the criterion variable became final course grade rather than success/nonsuccess.

Three scale factors were found statistically significant, as presented in Table 7. High perceived academic control (PAC) showed the greatest effect size, explaining 30\% of the variation in final grade. The five remaining scale factors, as well as three nonscale variables, failed to reveal a statistically significant association with final course grade. 
Table 7.

Somers' Delta Results

\begin{tabular}{lcc}
\hline & Somers' d & Approx. Sig. \\
\hline High PAC & .299 & $.003 *$ \\
High Teaching Presence & .181 & $.007 *$ \\
High Social Support of Special Person & .161 & $.048 * *$ \\
\hline
\end{tabular}

* significant at the $p<.01$ level. ** significant at the $p<.05$ level

In subsequent Mann-Whitney U tests (Pallant, 2013), significance was confirmed for the scales of PAC and teaching presence. Final grades among students with high PAC (mean rank= 134.38) were significantly higher than among students with lower PAC (mean rank $=95.94),(U$ $=2788.000, z=-3.013, p=.003)$. Final grades among students who reported high teaching presence (mean rank $=139.87$ ) were significantly higher than among students who reported lower teaching presence (mean rank $=116.59),(U=6730.500, z=-2.623, p=.009)$.

\section{Phase Three Results}

Six strong themes emerged during coding and analysis of Phase Three interviews. Themes are described below, using exemplar quotes. While pseudonyms have been used to protect individual identity, general demographics and course characteristics are included in Tables 3 and 4.

Time management. Each participant considered time management critical to success in online courses. Many tied time management to scheduling. As Debra explained, in a face-to-face class the schedule is set for you: "You have to be at class from 9:00 am until noon, and during that three-hour block that's where you are. You're in class." Whereas, online, "you have the entire week to figure out your time allotment of what you're going to do and how and when."

Chloe, Gina, and Laura all described their use of student planners to manage homework and deadlines. Ingrid and Karen talked about creating master calendars of assignments and due dates. Beth blocked off time each morning and worked on her online course as if she were attending a class in person. Chloe set aside a specific day each week to complete online course assignments. In addition to scheduling and time allocation, participants linked time management with organization and prioritization.

Supportive family. All interviewees acknowledged the importance of family support. As a single mom, Haley recognized her parents and sister, saying, "They'll watch my kids while I go take the proctored exams or even just for me to read homework in silence." Debra and Janet both mentioned husbands picking up additional household responsibility, such as cooking meals. Karen described the power of encouragement, saying, "Maybe you have this passing thought in your head that you think it's not possible, but you have your parents or your family saying, 'you can do this, you absolutely can."' 
Teaching presence. All interviewees felt the role of the instructor was vital to student success. The vast majority expressed appreciation for quick instructor response to their emails. Janet commented that instructor feedback made the course feel more personal. Haley thought the addition of media enhanced teaching presence, especially if it included the instructor's own voice. She said, "I feel like that shows a professor really cares that you're learning what they're trying to teach you rather than just relying on the book to teach you." Likewise, Ingrid reflected on the absence of recorded lectures by saying, 'It's just 'do this stuff for your grade.' You're just reading from the textbook or watching other things that aren't the professor. It's really hard to remember that there is [a professor]."

Student initiative. Student initiative was a common theme, although participants used a variety of terms to describe it. Some talked about self-motivation, "being driven," or being a "selfstarter," while others called it "being proactive." Ethan thought a higher level of self-regulation was required of online students. When asked for examples of initiative, students described proactively contacting the instructor. Beth observed, "The student has to be a lot more proactive when it's an online class...especially students who wouldn't typically ask questions in class or really engage with the professor."

Social interaction. The level of interaction varied between courses. Further, the way in which participants described interaction varied. Five students indicated they had no interaction with other students in the online class. However, some of those same students talked about required participation in the class discussion board. When pressed to explain the apparent discrepancy, they did not consider activity on the discussion board the same thing as interaction. Haley characterized it as one-way communication, saying the discussion board is "like someone is speaking, but it's not a conversation." Finally, the perception of value also varied. Upperclassmen and graduate students generally expressed more appreciation for the discussion boards than underclassmen. For example, having taken both undergraduate and graduate courses online, Laura stated, "Online grad courses have been much richer."

Teach yourself. Four interviewees used some variation of the phrase "teach yourself." The phrase appeared to hold multiple meanings. Related to time management and scheduling, Faye said, "Obviously we are the student, but I think when it comes to the online course, we're also the professor because we have to teach ourselves." She described her online course saying, "It was very student-paced and I think that kind of put the student in the professor's position. You taught yourself."

When referring to face-to-face courses, Janet said, "You are getting those academic conversations. You are getting reminders. You might be getting bits of information from other students on things that you missed." She then contrasted that environment to the online situation, saying, "When it's online and you're not meeting regularly and may never meet any of the other students or the instructor, you really have to drive that train yourself."

Chloe commented, "In the online class, you are both the teacher and the student. There's no one there. I mean, you're kind of your own supervisor and there's no one to remind you that you have assignments to do." However, she went on to expand the meaning of being "both the teacher and the student" by saying, "No one's going to be there to really actually explain. You can't go to the classroom and expect the lesson to be gone over that day." She seemed to juxtapose verbal explanation with written explanation, saying, "In an online class, they provide you with the tools and resources to teach yourselves pretty much." 
Although they did not use the phrase teach yourself, other students also addressed differences between spoken and written communication. Beth compared the content delivery of two different online courses she had taken. "In my pre-calculus class," she said, "the instructor always had a screencast that she would upload where she would basically teach the lesson as if she was teaching it on a whiteboard...there was voiceover as well." She then related, "The STAT class didn't have that, which was kind-of disappointing. He would send out lessons that were summaries of the chapter, essentially, which were a little more difficult to follow than the screencast." Ingrid commented, "Sometimes you get exhausted from just reading, reading, reading - never hearing someone's voice and never hearing it summed up in a really nice way."

Ethan found it more interesting to learn certain subjects on his own and felt online courses were geared for students who liked to "self-teach." Together with self-paced scheduling and written explanation, students seemed to embed the idea of independent research into the concept of "teaching yourself."

\section{Comprehensive Results}

Having used an explanatory sequential design, all results were analyzed comprehensively at the close of the final phase. These aggregate results revealed significant association between student success and factors that may be categorized as personal, circumstantial, or course variables. For Phases One and Two, variables were intentionally selected based on a theoretical framework that included these categories. Themes emerging from elaborative qualitative analysis in the third phase fell naturally into the framework of personal, circumstantial, and course characteristics.

By design, each successive phase in the explanatory sequential exploration yielded more substantive information. For example, in Phase Two students with higher levels of perceived academic control were shown to earn significantly higher course grades. Expectancy beliefs related to perceived academic control were illustrated in the interviews as students discussed time management, student initiative, and ways in which they "taught themselves" in an online course.

\section{Discussion}

The explanatory sequential design provided the foundation for a cohesive and in-depth evaluation of factors related to student success. Quantitative results revealed statistically significant relationships between success in online courses and seven individual factors: three personal variables (cumulative GPA, race, and perceived academic control), two circumstantial variables (class standing and degree level), and two course variables (course level and teaching presence). Cumulative GPA demonstrated the largest effect size among the seven factors. To evaluate combinations of variables and develop predictive models of student success, logistic regression was used and revealed that the variables predictive of success changed with students' level of academic experience. Interviews with successful students provided deeper insights into their perceptions and experiences. Their comments about personal characteristics and actions coalesced into themes of time management and student initiative, as well as the surprising "teach yourself" theme. Descriptions of their online course experience merged into themes of teaching presence and social interaction. Finally, interviewees discussed the roles of challenges and family support as circumstantial elements pertaining to their success. Although the current study was limited to a single institution, findings may be relevant to inform research at other institutions given the large number of cases and that nearly $10 \%$ of cases were students outside the state. 
Among prior studies, the personal characteristic of GPA produced more consistent evidence of correlation with student success than any other variable (e.g., Cochran et al., 2014; Hachey, Wladis, \& Conway, 2014). The logistic regression analysis in the current study corroborates these findings, supporting the conclusion that students who generally do well academically are more likely to do well in online courses too. Hence, targeted interventions to enhance success in online courses might be directed toward students who are not succeeding overall. While this study focused on successful students, future studies that include nonsuccessful students are warranted.

It should be noted that cumulative GPA was captured at the end of the semesters indicated, thereby including the online course being analyzed. Hence, the online course provided a proportionally larger contribution toward cumulative GPA for first-year students compared to seniors. Given the volume of cases and the consistency of findings across all class levels, this issue likely did not impact the conclusions. Further, using the cumulative GPA prior to the semester of analysis would exclude the first semester of first-year students as well as grades in other classes being taken by students during the same semester of analysis.

A statistically significant association between the personal variable of race and success in online courses was revealed, although the effect size was small. More than a quarter of students in the current study declined to disclose their race and were therefore categorized as "unknown race," likely skewing the conclusions about the relationship between race and success rates and providing no basis for settling discrepant findings in previous research.

Results of the current study indicated a significant relationship between the circumstantial variable of degree level and online course success, again with a small effect size. As might be expected, graduate students achieved the highest success rates in their online courses while nondegree-seeking students had the lowest success rates. Graduate student success could be attributed to their academic longevity or to having focused on a disciplinary area of specific interest and application to their careers. Among undergraduate students, those seeking the lowest level of academic credential (a subassociate occupational endorsement) had the highest online course success rates. Students in this category are typically pursuing workforce development and taking courses immediately applicable to their employment. These results may be indicative of student motivation or may speak to the student's perception of course relevance. Joo, Lim, and Kim (2013) found that perceived relevance of assigned tasks within a course exerted a significant effect on achievement, and Park and Choi (2009) concluded that perceived course relevance had a significant effect on course completion. One strength of the current study was the unique breadth of degree levels available for inquiry at a single institution. The inclusion of a microcredential such as the occupational endorsement may have strengthened the analyses, allowing for the discrepant conclusion that degree level is a contributing factor of success.

\section{Class Standing and Course Level}

Findings in the current study also indicated that class standing, a circumstantial variable, had a significant relationship with success in online courses. Graduate students were shown to have the highest course success rates. Seniors had the second-highest success rates, followed (in descending order) by juniors, sophomores, non-degree-seeking students, first-time freshmen, and continuing freshmen. These results add to evidence of an association between class standing and success, as reported by Cochran et al. (2014) and Levy (2007), indicating that academic experience 
progressively scaffolds student success. The finding that first-time freshmen had higher success rates than continuing freshmen is a curious, contradictory result that warrants further exploration.

Results of this study also showed online course level, a course variable, to have a significant, positive relationship with student success, which appears to be a unique contribution to the body of knowledge. Students tend to have more success in courses with higher academic complexity. While this success may be influenced by age, academic experience, and maturity, the link between these factors is not exclusive. Newer students, such as first year and sophomores, sometimes enroll in upper division courses. More frequently, seniors complete a few remaining general education requirements just prior to graduation.

More noteworthy than the simple association between student success and the individual variables of class standing or course level was the discovery that predictive models of combined factors contributing to success differed between various class-standing groups. For example, the combination of variables that predicted success among first-time freshmen differed from variables contributing to success among continuing freshmen. Success is complex, as are the factors that determine it. The current results with supportive evidence in all three phases indicated that factors related to success appear to change with a student's level of academic experience. Interviewing more individuals from each class level in future studies will further enhance the understanding of these interrelationships. Evaluating factors of success across multiple class levels in a single study provided a unique and significant contribution that may help to explain some of the contradictions in previous research. Some previous studies, for example, considered targeted populations, such as community college students (Hachey et al., 2014; Jost et al., 2012) or graduate students (Rakap, 2010; Rockinson-Szapkiw et al., 2016). Other studies evaluated a broad population without examining the predictive factors for a given subpopulation (Levy, 2007; Wang et al., 2013).

Similar to other class modalities, findings of the current study implied that design and delivery of online classes should consider students' current academic level. Online classes designed for sophomores compared to those for seniors therefore need to be different for reasons beyond just the varied level of students' cognitive capacity. Differences in predictive models could also have implications for comprehensive student advising and online student support. Awareness of the factors associated with success at each level of academic experience may empower academic personnel to provide more targeted and effective support.

Evidence that success factors change with academic experience also supports the conclusion that student success is a synergistic relationship between personal, circumstantial, and course variables. As such, these variables are best studied in an ecological fashion rather than in isolation. This conclusion sounds intuitive; theoretical models agree that student success is contextually sensitive and may be influenced by a combination of elements (Bean \& Metzner, 1985; Berge \& Huang, 2004; Rovai, 2003; Tinto, 1993). Yet relatively few studies have examined objective course outcomes of online students in a comprehensive manner that includes personal, circumstantial, and course variables. If research is to be translated to practice of design, delivery and policy making, it is essential to understand determinants of success at a deeper level than the role of single variables. For example, if an instructor considers only one variable at a time when designing and delivering an online course, the role of that variable and its interrelationship with others is missed. 


\section{Perceived Academic Control}

The PAC questionnaire, distributed in the second phase of research, assessed students' expectancy beliefs through quantitative analysis of scale scores. The findings suggest that students who believe they have a high level of control over academic outcomes may earn higher course grades. In the third phase of research, qualitative interviews with successful students reflected these expectancy beliefs of PAC as students talked about time management, student initiative, and the need to teach themselves. When asked how they were able to overcome circumstantial challenges and persist to completion, participants spoke of the personal characteristics of determination, self-motivation, hard work, and help-seeking behavior.

These characteristics are congruent with Bandura's (1991) discussion of locus of control, which is concerned with whether an individual believes outcomes are determined by their own actions (internal locus of control) or by forces outside their control (external locus of control). Locus of control has been demonstrated as a predictor of academic success in numerous studies related to traditional classrooms (Perry et al., 2001; Stupnisky, Perry, Hall, \& Guay, 2012). However, locus of control has shown mixed results among studies of online students. The PAC scale used in this study is domain specific, developed to assess college students' beliefs about academic success (Perry et al., 2001). Current results indicated students with high PAC-scale scores earn higher course grades than students with lower PAC scores. This finding adds to prior evidence that internal locus of control is associated with success in online courses (Lee, Choi, \& Kim, 2013; Rogers, 2015).

An important limitation in the current study was the lack of variance among Phase Two respondents. It is unclear whether all successful online students have an equally high level of perceived academic control, or whether internal locus of control prompted this particular set of students to respond to the questionnaire. It would be valuable to extend the study to nonsuccessful students, in order to determine whether the variables of perceived academic control and perception of teaching presence differ between successful and unsuccessful students. Likewise, it would be beneficial to expand the number of student interviews to broaden the understanding and generalizability of student perceptions.

\section{Teaching Presence}

The current study examined two elements from the CoI process model developed by Garrison and colleagues (2000). Teaching presence was shown to have a statistically significant relationship to final course grade; social presence was not statistically significant. This was confirmed in interviews when students described teaching presence as substantially more important to their success than interaction with other students within the course.

Prior empirical evidence for association between teaching presence and final course grade was scarce. Results of this study revealed final grades to be higher among students who reported high teaching presence than among students who reported lower teaching presence, in agreement with findings by Rockinson-Szapkiw et al. (2016). This finding suggests that success rates in online courses might be improved by increasing practices related to teaching presence.

During interviews, students were asked, "What role did the instructor play in helping you succeed in this course?" Students described several elements of teaching presence, such as responding promptly to emails, providing personal feedback on assignments, providing reminders, and recording lectures as audio or screencasts. Participants discussed the online instructor's role 
in contrast to the in-person classroom instructor's role. In face-to-face classrooms, they thought the instructor's role was to lecture and explain, while online, the instructor's role was to guide and provide resources. This description of instructor roles did not necessarily reflect student ideals but was a description of their lived experience. It followed that several participants said the online student role was, in part, to teach oneself.

\section{Teach Yourself}

"Teach yourself" was, in fact, one of the most interesting and surprising themes to emerge from the interviews. Student statements related to teaching themselves seemed puzzling at first, given that the same students reported online instructors to be instrumental to their learning. Three elements of "teach yourself" emerged in their descriptions. First, online students are responsible for their own schedules and effort regulation, to a much greater degree than what is expected of students in classroom courses. Second, online course material is often delivered in written form, while in-class lectures are usually delivered verbally. Some students seemed to equate teaching with oral presentation. These students implied that written presentation necessitated "selfteaching." Finally, students indicated that online courses required more independent research than in-person courses.

When an instructor delivered lecture material in written form, or explained something using text rather than speech, students tended to call the activity guidance rather than teaching. This dichotomy raises interesting questions. It might be construed that reading, by its very nature, is a more active endeavor than listening. However, it is also plausible that students have been conditioned through past educational experience to equate teaching with verbal presentation. Rogers (2015) argued that students have come to expect a lecture format because that is what they have traditionally experienced. As students move from high school to college, they are expected to become more responsible and self-directed (Wadsworth, Husman, Duggan, \& Pennington, 2007). Nevertheless, unanswered questions about student perceptions of reading versus listening provide an opportunity for further research. This question might be explored by comparing groups of students with various educational backgrounds. For example, perceptions of students who completed high school via homeschooling might be compared to perceptions of students who graduated from public or private high schools.

Researchers who developed the CoI model, which encompasses teaching presence and social presence, called text-based communication a "lean medium," acknowledging that it lacked the richness of verbal communication. On the other hand, they believed it might be advantageous for rigorous cognitive learning because it slows interaction time and allows opportunity for reflection (Garrison et al., 2000). Graduate students in the current study seemed to support that notion, expressing appreciation for the egalitarian nature of online discussions with peers. By contrast, the underclassmen who were interviewed found discussion board participation less meaningful. Post hoc evaluation of social presence scale scores among the 12 interviewees confirmed that graduate students rated social presence higher than undergraduates, although the sample size is certainly too small to draw conclusions. Interestingly, the CoI model was originally developed through research on graduate-level courses. 


\section{Conclusion}

An explanatory sequential research design in the present study afforded deeper understanding of the factors related to online student success, perhaps addressing some of the contradictions in previous studies. The current mixed methods design was a useful reciprocal tool since qualitative results augmented quantitative results, and the latter confirmed the accuracy of interviewees' comments. Students who were successful in online courses offered a valuable perspective about what contributes to their success - a piece that is often missing when administrators and faculty try to improve online experiences. This strengths-based approach was a key to understanding factors of success, providing opportunities for inclusion strategies that can complement existing deficit-based exclusion strategies when designing and delivering online courses. While the term success can be operationalized in so many ways, it remains contextsensitive and multifaceted, thereby necessitating more complex investigative approaches to understanding underlying factors. 


\section{References}

Allen, I. E., \& Seaman, J. (2013). Changing course: Ten years of tracking online education in the United States. Newburyport, MA: Sloan Consortium. Retrieved from https://onlinelearningconsortium.org/survey_report/changing-course-ten-years-trackingonline-education-united-states/

Allen, I. E., \& Seaman, J. (2017). Digital learning compass: Distance education enrollment report 2017. Babson Park, MA: Babson Survey Research Group. Retrieved from http://digitallearningcompass.org/

Allen, I. E., Seaman, J., Poulin, R., \& Straut, T. T. (2016). Online report card: Tracking online education in the United States. Babson Park, MA: Babson Survey Research Group and Quahog Research Group, LLC.

Aragon, S. R., \& Johnson, E. S. (2008). Factors influencing completion and noncompletion of community college online courses. American Journal of Distance Education, 22(3), 146158.

Asplund, J., Lopez, S. J., Hodges, T., \& Harter, J. (2007). The Clifton StrengthsFinder ${ }^{\circledR} 2.0$ technical report: Development and validation. Princeton, NJ: The Gallup Organization.

Bandura, A. (1991). Social cognitive theory of self-regulation. Organizational Behavior and Human Decision Processes, 50, 248-287.

Baturay, M. H., \& Yukselturk, E. (2015). The role of online education preferences on student's achievement. Turkish Online Journal of Distance Education, 16(3), 3-12.

Bean, J. P., \& Metzner, B. S. (1985). A conceptual model of nontraditional undergraduate student attrition. Review of Educational Research, 55(4), 485-540.

Berge, Z. L., \& Huang, Y. -P. (2004). A model for sustainable student retention: A holistic perspective on the student dropout problem with special attention to e-learning. DEOSNEWS, 13(5), 1-26.

Boston, W. E., Ice, P., \& Gibson, A. M. (2011). Comprehensive assessment of student retention in online learning environments. Online Journal of Distance Learning Administration, 4(1). Retrieved from http://www.westga.edu/ distance/ojdla/spring141/boston_ice_gibson141.html

Carnevale, A. P., Strohl, J., \& Smith, N. (2009). Help wanted: Postsecondary education and training required. New Directions for Community Colleges, 146, 21-31.

Clark, M. (2013). Student success and retention: Critical factors for success in the online environment (Doctoral dissertation). Retrieved from UNF Theses and Dissertations. Paper 444.

Clinefelter, D. L., \& Aslanian, C. B. (2016). Online college students 2016: Comprehensive data on demands and preferences. Louisville, KY: The Learning House, Inc.

Cochran, J. D., Campbell, S. M., Baker, H. M., \& Leeds, E. M. (2014). The role of student characteristics in predicting retention in online courses. Research in Higher Education, $55(1), 27-48$. 
Craven, R. G., Ryan, R. M., Mooney, J., Vallerand, R. J., Dillon, A., Blacklock, F., \& Magson, N. (2016). Toward a positive psychology of indigenous thriving and reciprocal research partnership model. Contemporary Educational Psychology, 47, 32-43.

Creswell, J. W. (2011). Controversies in mixed methods research. In N. K. Denzin \& Y. S. Lincoln (Eds.), The Sage handbook of qualitative research (4 ${ }^{\text {th }}$ ed., pp. 269-283). Los Angeles, CA: Sage.

Dew, J. P., Anderson, B. L., Skogrand, L., \& Chaney, C. (2017). Financial issues in strong African American marriages: A strengths-based qualitative approach. Family Relations, 66(2), 287-301.

Dweck, C. S. (2013). Self-theories: Their role in motivation, personality, and development. Hoboken, NJ: Taylor and Francis.

Ekstrand, B. (2013). Prerequisites for persistence in distance education. Online Journal of Distance Learning Administration, 16(3). Retrieved from http://www.westga.edu/ distance/ojdla/fall163/ekstrand164.html

Fenton, A., Walsh, K., Wong, S., \& Cumming, T. (2015). Using strengths-based approaches in early years practice and research. International Journal of Early Childhood, 47(1), 27 52.

Garrison, D. R., Anderson, T., \& Archer, W. (2000). Critical inquiry in a text-based environment: Computer conferencing in higher education. The Internet and Higher Education, 2(2), 87-105.

Gibson, A., Kupczynski, L., \& Ice, P. (2010). Student success in top 20 courses of an online institution: Demographic differences in a multi-semester cross-curricular study. $i$ Manager's Journal of Educational Technology, 7(2), 18-26.

Glazier, R. A. (2016). Building rapport to improve retention and success in online classes. Journal of Political Science Education, 12(4), 437-456.

Gordon, R. A. (2015). Regression analysis for the social sciences (2nd ed.). New York, NY: Routledge.

Guidry, K. (2013). Predictors of student success in online courses: Quantitative versus qualitative subject matter. Journal of Instructional Pedagogies, 10, 1-13.

Hachey, A. C., Wladis, C. W., \& Conway, K. M. (2014). Do prior online course outcomes provide more information than GPA alone in predicting subsequent online course grades and retention? An observational study at an urban community college. Computers \& Education, 72, 59-67.

Harrell, I. L., \& Bower, B. L. (2011). Student characteristics that predict persistence in community college online courses. American Journal of Distance Education, 25(3), 178 191.

Hart, C. (2012). Factors associated with student persistence in an online program of study: A review of the literature. Journal of Interactive Online Learning, 11(1), 19-42. 
Hegeman, J. (2015). Using instructor-generated video lectures in online mathematics courses improves student learning. Online Learning, 19(3), 70-87.

Herbert, M. (2006). Staying the course: A study in online student satisfaction and retention. Online Journal of Distance Learning Administration, 9(4), 300-317.

Jaggars, S., \& Xu, D. (2010). Online learning in the Virginia Community College System. Community College Research Center, Columbia University. Retrieved from https://files.eric.ed.gov/fulltext/ED512396.pdf

Joo, Y. J., Lim, K. Y., \& Kim, J. (2013). Locus of control, self-efficacy, and task value as predictors of learning outcome in an online university context. Computers \& Education, $62,149-158$.

Jost, B., Rude-Parkins, C., \& Githens, R. P. (2012). Academic performance, age, gender, and ethnicity in online courses delivered by two-year colleges. Community College Journal of Research and Practice, 36(9), 656-669.

Kelderman, E. (2013, January 10). Lumina Foundation adopts new tactics to reach collegecompletion goal. The Chronicle of Higher Education.

Layne, M., Boston, W. E., \& Ice, P. (2013). A longitudinal study of online learners: Shoppers, swirlers, stoppers, and succeeders as a function of demographic characteristics. Online Journal of Distance Learning Administration, 16(2). Retrieved from http://www.westga.edu/ distance/ojdla/.

Lee, Y., \& Choi, J. (2011). A review of online course dropout research: Implications for practice and future research. Educational Technology Research and Development, 59(5), 593618.

Lee, Y., Choi, J., \& Kim, T. (2013). Discriminating factors between completers of and dropouts from online learning courses. British Journal of Educational Technology, 44(2), 328337.

Lee Duckworth, A., Steen, T. A., \& Seligman, M. E. (2005). Positive psychology in clinical practice. Annual Review of Clinical Psychology, 1, 629-651.

Levy, Y. (2007). Comparing dropouts and persistence in e-learning courses. Computers \& Education, 48(2), 185-204.

Liu, S. Y., Gomez, J., \& Yen, C. (2009). Community college online course retention and final grade: Predictability of social presence. Journal of Interactive Online Learning, 8(2), 165-182.

Lokken, F. (2017). Trends in elearning: Tracking the impact of elearning at community colleges. Washington, DC: Instructional Technology Council.

Lopez, S. J., \& Louis, M. C. (2009). The principles of strengths-based education. Journal of College and Character, 10(4). http://dx.doi.org/10.2202/1940-1639.1041 
Maton, K. I., Dodgen, D. W., Leadbeater, B. J., Sandler, I. N., Schellenbach, C. J., \& Solarz, A. L. (2004). Strengths-based research and policy: An introduction. In K. I. Maton, C. J. Schellenbach, B. J. Leadbeater, \& A. L. Solarz (Eds.), Investing in children, youth, families, and communities: Strengths-based research and policy (pp. 3-12). Washington, DC: American Psychological Association.

National Adult Learner Coalition. (2017, February). Strengthening America's economy by expanding educational opportunities for working adults. Retrieved from https://onlinelearningconsortium.org/wp-content/uploads/2017/02/StrengtheningAmericas-Economy-National-Adult-Learning-Coalition-White-Paper-Final.pdf

Olson, J. S., \& McCracken, F. E. (2014). Is it worth the effort? The impact of incorporating synchronous lectures into an online course. Online Learning, 19(2). http://dx.doi.org/10.24059/olj.v19i2.499

Pallant, J. (2013). SPSS survival manual: A step by step guide to data analysis using IBM SPSS. Maidenhead, United Kingdom: Open University Press.

Park, J. -H., \& Choi, H. J. (2009). Factors influencing adult learners' decision to drop out or persist in online learning. Educational Technology \& Society, 12(4), 207-217.

Perry, R. P., Hladkyj, S., Pekrun, R. H., \& Pelletier, S. T. (2001). Academic control and action control in the achievement of college students: A longitudinal field study. Journal of Educational Psychology, 93(4), 776-789.

Rakap, S. (2010). Impacts of learning styles and computer skills on adult students' learning online. TOJET: The Turkish Online Journal of Educational Technology, 9(2), 108-115.

Rockinson-Szapkiw, A., Wendt, J., Wighting, M., \& Nisbet, D. (2016). The predictive relationship among the Community of Inquiry framework, perceived learning and online, and graduate students' course grades in online synchronous and asynchronous courses. The International Review of Research in Open and Distributed Learning, 17(3). http://dx.doi.org/10.19173/irrodl.v17i3.2203

Rogers, P. R. (2015). Student locus of control and online course performance: An empirical examination of student success in online management courses. Academy of Educational Leadership Journal, 19(3), 261-270.

Rovai, A. P. (2003). In search of higher persistence rates in distance education online programs. The Internet and Higher Education, 6(1), 1-16.

Saldaña, J. (2009). The coding manual for qualitative researchers. Thousand Oaks, CA: Sage.

Saleebey, D. (2006). The strengths perspective in social work practice (4th ed.). Boston: Pearson/Allyn \& Bacon.

Schwarzer, R., \& Jerusalem, M. (2009). The general self-efficacy scale (GSE). Anxiety, Stress, and Coping, 12, 329-345.

Shaima, N., \& Narayanan, G. (2018). A glass half full not empty: Strength-based practice in persons with substance use disorders. Psychological Studies, 63(1), 19-25. doi:10.1007/s12646-017-0433-7. 
Shushok, F., Jr., \& Hulme, E. (2006). What's right with you: Helping students find and use their personal strengths. About Campus, 11(4), 2-8.

Simpson, O. (2006). Predicting student success in open and distance learning. Open Learning, 21(2), 125-138.

Soares, L. (2013, January). Post-traditional learners and the transformation of postsecondary education: A manifesto for college leaders. Retrieved from http://louissoares.com/wpcontent/uploads/2013/02/post_traditional_learners.pdf

Stebleton, M. J., Soria, K. M., \& Albecker, A. (2012). Integrating strength-based education into a first-year experience curriculum. Journal of College and Character, 13(2).

Stupnisky, R. H., Perry, R. P., Hall, N. C., \& Guay, F. (2012). Examining perceived control level and instability as predictors of first-year college students' academic achievement. Contemporary Educational Psychology, 37(2), 81-90.

Suphi, N., \& Yaratan, H. (2012). Effects of learning approaches, locus of control, socioeconomic status and self-efficacy on academic achievement: A Turkish perspective. Educational Studies, 38(4), 419-431.

Tinto, V. (1993). Leaving college: Rethinking the causes and cures of student attrition (2nd ed.). Chicago, IL: University of Chicago Press.

Verney, S. P., Avila, M., Espinosa, P. R., Cholka, C. B., Benson, J. G., Baloo, A., \& Pozernick, C. D. (2016). Culturally sensitive assessments as a strength-based approach to wellness in native communities: A community-based participatory research project. American Indian \& Alaska Native Mental Health Research: The Journal of the National Center, 23(3).

Wadsworth, L. M., Husman, J., Duggan, M. A., \& Pennington, M. N. (2007). Online mathematics achievement: Effects of learning strategies and self-efficacy. Journal of Developmental Education, 30(3), 6-14.

Wang, C. H., Shannon, D. M., \& Ross, M. E. (2013). Students' characteristics, self-regulated learning, technology self-efficacy, and course outcomes in online learning. Distance Education, 34(3), 302-323.

Watt, T. T., Norton, C. L., \& Jones, C. (2013). Designing a campus support program for foster care alumni: Preliminary evidence for a strengths framework. Children and Youth Services Review, 35(9), 1408-1417.

Williams, B., Onsman, A., \& Brown, T. (2010). Exploratory factor analysis: A five-step guide for novices. Australasian Journal of Paramedicine, 8(3). Retrieved from https://ajp.paramedics.org/index.php/ajp/article/view/93/90.

Yukselturk, E., \& Bulut, S. (2007). Predictors for student success in an online course. Educational Technology \& Society, 10(2), 71-83.

Zimet, G. D., Dahlem, N. W., Zimet, S. G., \& Farley, G. K. (1988). The multidimensional scale of perceived social support. Journal of Personality Assessment, 52(1), 30-41. 


\section{Appendix A}

\section{Phase Two Questions}

1. During Spring 2015 semester, what was your work situation?
a. I was working full time
b. I was working part time
c. I did not have a job

2. Did either of your parents graduate from college?
a. yes
b. no

3. During Spring 2015 semester, did you spend significant time and effort caring for others in your family, such as children, siblings, or elders?
a. yes
b. no

Please mark the level to which you agree or disagree with each of the following statements. (1, strongly disagree; 5, strongly agree)

4. My grades are basically determined by things beyond my control and there is little I can do to change that. (Reverse scoring.)

5. My family is willing to help me make decisions.

6. Your intelligence is something about you that you can't change very much. (Reverse scoring.)

7. I have a great deal of control over my academic performance in my online courses.

8. No matter what academic challenge comes my way, I'm usually able to handle it.

9. If I am in a bind in my courses, I can usually think of something to do.

10. I can count on my friends when things go wrong.

11. My friends really try to help me.

12. I can solve most academic problems if I invest the necessary effort.

13. I see myself as largely responsible for my performance throughout my college career.

14. When I encounter an academic obstacle, I can find a way to overcome it.

15. Thanks to my resourcefulness, I know how to handle unforeseen situations in my academic career.

16. I can talk about my problems with my friends.

17. You can always substantially change how intelligent you are.

18. My family really tries to help me.

19. There is little I can do about my college performance. (Reverse scoring.)

20. There is a special person with whom I can share my joys and sorrows.

21. I can always manage to solve difficult academic problems if I try hard enough.

22. The more effort I put into my courses, the better I do in them.

23. I can talk about my problems with my family.

24. It is easy for me to stick to my aims and accomplish my academic goals.

25 . No matter who you are, you can significantly change your intelligence level.

26. You can learn new things, but you can't really change your basic intelligence. (Reverse scoring.) 
27. How well I do in my courses is often the "luck of the draw." (Reverse scoring.)

28. No matter what I do, I can't seem to do well in my courses. (Reverse scoring.)

29. No matter how much intelligence you have, you can always change it quite a bit.

30. When I do poorly in a course, it's usually because I haven't given it my best effort.

31. I have friends with whom I can share my joys and sorrows.

32. I have a special person who is a real source of comfort to me.

33. To be honest, you can't really change how intelligent you are. (Reverse scoring.)

34. You have a certain amount of intelligence, and you can't really do much to change it. (Reverse scoring.)

35. I can remain calm when facing academic difficulties because I can rely on my coping abilities.

36. I get the emotional help and support I need from my family.

37. There is a special person in my life who cares about my feelings.

38. You can change even your basic intelligence level considerably.

39. There is a special person who is around when I am in need.

40. When I am confronted with an academic problem, I can usually find several solutions.

41. I am confident that I can deal efficiently with unexpected academic challenges.

The email inviting you to participate in this research study referred to a specific online course. Please mark the level to which you agree with each of the following statements related to that specific course. (1, strongly disagree; 5, strongly agree)

42. Instructor actions reinforced the development of a sense of community among course participants.

43. I felt that my point of view was acknowledged by other course participants.

44. I felt comfortable disagreeing with other course participants while still maintaining a sense of trust.

45. The instructor provided clear instructions on how to participate in course learning activities.

46. The instructor helped to focus discussion on relevant issues in a way that helped me to learn.

47. Online or web-based communication is an excellent medium for social interaction.

48. The instructor clearly communicated important course topics.

49. Online discussions help me to develop a sense of collaboration.

50. The instructor was helpful in guiding the class towards understanding course topics in a way that helped me clarify my thinking.

51. I felt comfortable participating in the course discussions.

52. I felt comfortable interacting with other course participants.

53. The instructor helped to keep the course participants on task in a way that helped me to learn.

54. The instructor helped to keep course participants engaged and participating in productive dialog.

55. The instructor provided feedback in a timely fashion.

56. The instructor provided feedback that helped me understand my strengths and weaknesses relative to the course's goals and objectives.

57. I was able to form distinct impressions of some course participants. 
58. Getting to know other course participants gave me a sense of belonging in the course.

59. The instructor clearly communicated important course goals.

60. The instructor encouraged course participants to explore new concepts in this course.

61. The instructor clearly communicated important due dates/time frames for learning activities.

62. The instructor was helpful in identifying areas of agreement and disagreement on course topics that helped me to learn.

63. I felt comfortable conversing through the online medium. 